\title{
PEMBELAJARAN MATEMATIKA BERBANTUAN SOFTWARE ALGEBRATOR UNTUK MENINGKATKAN KEMAMPUAN PEMAHAMAN MATEMATIS SISWA
}

\author{
Uba Umbara ${ }^{1}$, Inri Rahmawati ${ }^{2}$ \\ ${ }^{1,2}$ STKIP Muhammadiyah Kuningan \\ uba.bara@upmk.ac.id
}

\begin{abstract}
Abstrak
Kemampuan pemahaman matematis siswa menjadi penting untuk dikuasai. Pemahaman matematis juga merupakan salah satu tujuan dari setiap materi yang disampaikan oleh guru, sebab guru merupakan pembimbing siswa untuk mencapai konsep yang diharapkan. Meskipun telah disebutkan bahwa kemampuan pemahaman matematis sangat diperlukan siswa, namun pada kenyataannya dilapangan kemampuan ini masih belum dikuasi secara utuh oleh siswa. Penelitian ini bertujuan untuk mengkaji perbandingan kemampuan pemahaman matematis siswa yang menerapkan pembelajaran berbantuan Software Algebrator dan siswa yang menggunakan pembelajaran biasa serta menelaah perbedaan peningkatan kemampuan pemahaman matematis siswa yang menerapkan pembelajaran berbantuan Software Algebrator dan siswa yang menggunakan pembelajaran biasa. Metode penelitian yang digunakan dalam penelitian ini adalah kuasi eksperimen dengan desain kelompok kontrol non-ekuivalen (non equivalent control group design). Hasil pengujian hipotesis menunjukan bahwa terdapat perbedaan peningkatan kemampuan pemahaman matematik yang signifikan antara siswa dengan tingkat kemampuan tinggi, sedang dan rendah. Hal ini dimungkin bahwa peningkatan kemampuan pemahaman matematik siswa dipicu oleh pembelajaran matematika berbantuan Software Algebrator yang dalam pelaksanaan pembelajarannya selalu memperhatikan prinsip student centered.
\end{abstract}

Kata kunci: Pembelajaran Matematika, Software Algebrator, Kemampuan Pemahaman Matematik

\begin{abstract}
The students' mathematical understanding is important to master. Mathematical understanding is also one of the goals of each material presented by the teacher, because the teacher is a guide to achieve the expected concept. Although already has the ability of a mathematical language is needed, but the belief in the field of this ability is still not fully reinforced by students. This study aims to examine the comparison of the ability to understand mathematically students who apply Algebrator software-assisted learning and students who use regular learning and examine differences in the ability to improve students' mathematical understanding of Algebrator-assisted learning software and students using ordinary learning. The research method used in this research is quasi experiment with non-equivalent control group design (unequal control group design). The result of hypothesis test shows that there is a difference in the ability of understanding of mathematics significantly between the students with high, medium and low ability level. This is possible by the improvement of mathematical ability of students triggered by Algebrator software-assisted mathematics learning which in the implementation of learning always pay attention to students centered.
\end{abstract}

Keywords: Mathematics Learning, Algebrator Software, Mathematical Understanding Skill 


\section{PENDAHULUAN}

Seperti yang sudah menjadi pembicaraan umum, matematika selalu dianggap sebagai pelajaran hitungan dan hapalan rumus belaka. Inilah yang menyebabkan siswa menjadi tidak tertarik untuk belajar matematika. Padahal tanpa mereka sadari, mereka telah menerapkan konsep-konsep matematika dalam kehidupan. Atas dasar inilah maka diperlukan suatu pemahaman akan arti penting matematika yang sebenarnya. Menurut Driver (Lestari, 2008) pemahaman adalah kemampuan untuk menjelaskan suatu situasi atau suatu tindakan. Dari pengertian ini terdapat 3 aspek pemahaman yaitu kemampuan mengenal, menjelaskan, dan menarik kesimpulan. Pemahaman merupakan bagian yang penting dalam proses belajar. Kemampuan memahami konsep menjadi landasan untuk berpikir dalam menyelesaikan persoalan.

Bahasan tentang pemahaman juga dikemukakan oleh Ruseffendi (2006), ada tiga macam pemahaman matematik, yaitu: pengubahan (translation), pemberian arti (interpretation) dan pembuatan ekstrapolasi (extrapolation). Pemahaman translasi digunakan untuk menyampaikan informasi dengan bahasa dan bentuk yang lain dan menyangkut pemberian makna dari suatu informasi yang bervariasi. Interpretasi digunakan untuk menafsirkan maksud dari bacaan, tidak hanya dengan kata-kata dan frase, tetapi juga mencakup pemahaman suatu informasi dari sebuah ide. Sedangkan ekstrapolasi mencakup estimasi dan prediksi yang didasarkan pada sebuah pemikiran, gambaran kondisi dari suatu informasi, juga mencakup pembuatan kesimpulan dengan konsekuensi yang sesuai dengan informasi jenjang kognitif ketiga yaitu penerapan (application) yang menggunakan atau menerapkan suatu bahan yang sudah dipelajari ke dalam situasi baru, yaitu berupa ide, teori atau petunjuk teknis.

Bloom (Tim MKPBM UPI, 2001) mengklasifikasikan pemahaman (comprehension) ke dalam jenjang kognitif kedua yang menggambarkan suatu pengertian, sehingga siswa diharapkan mampu memahami ide-ide matematika bila mereka dapat menggunakan beberapa kaidah yang relevan. Dalam tingkatan ini siswa diharapkan mengetahui bagaimana berkomunikasi dan menggunakan idenya untuk berkomunikasi. Dalam pemahaman tidak hanya sekedar memahami sebuah informasi tetapi termasuk juga keobjektifan, sikap dan makna yang terkandung dari sebuah informasi. Dengan kata lain seorang siswa dapat mengubah suatu informasi yang ada dalam pikirannya ke dalam bentuk lain yang lebih berarti.

Kemampuan pemahaman matematis adalah salah satu tujuan penting dalam pembelajaran, memberikan pengertian bahwa materi-materi yang diajarkan kepada siswa 
bukan hanya sebagai hafalan, namun lebih dari itu dengan pemahaman siswa dapat lebih mengerti akan konsep materi pelajaran itu sendiri. Pemahaman matematis juga merupakan salah satu tujuan dari setiap materi yang disampaikan oleh guru, sebab guru merupakan pembimbing siswa untuk mencapai konsep yang diharapkan. Hendriana dan Sumarmo (2014) menyatakan bahwa sesungguhnya pemahaman matematik memiliki tingkat kedalaman tuntutan kognitif yang berbeda, misalnya : seorang siswa SMP diakatakan memahami hukum asosiatif cukup bila ia dapat menerapkan sifat itu dengan benar.

Dari contoh tersebut, nampak jelas bahwa pemahaman matematika dapat mengantarkan siswa untuk menghubungkan pengetahuan dan memahami konsep serta apliksinya secara komprehensif. Namun demikian, pengetahuan dan pemahaman siswa dalam matematika termasuk kedalam kemampuan matematika yang paling simple/rendah jika dibandingkan dengan kemampuan lain. Polya (Sumarmo, 2013) merinci kemampuan pemahaman pada empat tahap yaitu: (1) pemahaman mekanikal yang dicirikan dengan dapat mengingat dan menerapkan rumus secara rutin dan menghitung secara sederhana; (2) pemahaman induktif yang dicirikan dengan dapat mengingat dan menerapkan rumus atau konsep dalam kasus sederhana atau dalam kasus serupa; (3) pemahaman rasional yang dicirikan dengan dapat membuktikan kebenaran suatu rumus dan teorema; (4) pemahaman intuitif yang dicirikan dengan dapat memperkirakan kebenaran dengan pasti (tanpa ragu-ragu) sebelum menganalisa lebih lanjut.

Sementara itu, Skemp (Sumarmo, 2013), menggolongkan pemahaman dalam dua jenis yaitu: (1) pemahaman instrumental yaitu hafal konsep/prinsip tanpa kaitan dengan yang lainnya, dapat menerapkan rumus dalam perhitungan sederhana, dan mengerjakan perhitungan secara algoritmik; (2) pemahaman relasional yaitu dapat mengerjakan suatu konsep/prinsip dengan konsep/prinsip yang lainnya. Sehingga, dapat disimpulkan bahwa kemampuan pemahaman matematik adalah kemampuan siswa dalam menerapkan dan mengaplikasikan konsep-konsep matematika yang terkait satu sama lainnya ke dalam berbagai macam dan model bentuk perhitungan dan dapat menginterpretasikannya dalam bentuk lain.

Meskipun telah disebutkan bahwa kemampuan pemahaman matematis sangat diperlukan siswa, namun pada kenyataannya di lapangan kemampuan ini masih belum dikuasi secara utuh oleh siswa. Untuk itu diperlukan sebuah pembelajaran yang dapat memfasilitasi siswa untuk bisa mengembangkan kemampuan tersebut. Sebagai fasilitator dalam pembelajaran, seorang guru harus bisa memfasilitasi siswa dengan pembelajaran sebaik mungkin. Sebagai upaya untuk bisa meningkatkan kemampuan pemahaman matematis siswa, 
maka salah satu alternatif pemebelajaran yang diduga mampu meningkatkan kemampuan pemahaman matematis adalah pembelajaran berbantuan komputer atau yang lebih terkenal dengan pembelajaran menggunakan IT (Information Technology) atau juga dikenal dengan ICT (Information Communication Technology).

Pembelajaran menggunakan komputer berupa software kini mulai banyak digunakan. Hal ini dikarenakan pembelajaran berbasis IT memberikan kesempatan kepada siswa untuk memecahkan masalah secara individual, meningkatkan pengembangan pemahaman siswa terhadap materi yang disajikan, merangsang siswa belajar dengan penuh semangat, dan memberikan kemudahan kepada siswa untuk menentukan sendiri laju pembelajarannya (Wena, 2013). Beberapa software matematika kini telah berkembang dan tersedia secara gratis, seperti GeoGebra, Mapple, Scatterplot, Algebrator, dan lain-lain.

Azam Zakeri (Kalantarnia et. al, 2012) dalam penelitiannya mempelajari perbandingan pengaruh pendidikan bantuan software dan metode pendidikan tradisional tentang pembelajaran matematika untuk anak laki-laki kelas 6 dan menemukan hubungan yang signifikan antara kelompok eksperimen dan kelompok kontrol. Sementara itu, Khouybaba (2010) yang meneliti peran positif teknologi dalam pembelajaran matematika dan menggunakan Software Maple menemukan bahwa Software tersebut membantu siswa dengan imajinasi membantu siswa dalam penerapan akar persamaan secara praktis. Kedua penelitian tersebut menunjukkan bahwa pemanfaatan Software dalam pembelajaran matematika dapat membantu siswa. Penelitian ini mencoba untuk berfokus pada Software Algebrator guna membantu siswa dalam memahami konsep-konsep matematika.

Algebrator adalah salah satu software program aljabar yang paling kuat yang pernah dikembangkan untuk mengatasi masalah aljabar Anda yang paling sulit kepada mahasiswa, guru, pekerja profesional dan lembaga-lembaga pendidikan saat ini, yang akan melaksanakan pembelajaran aljabar. Cara penggunaannya pun mudah, cukup ketik soal dengan bantuan beberapa toolbar yang ada, algebrator akan membantu menyelesaikannya dengan langkahlangkah yang mudah dipahami sampai menemukan solusinya. Software Algebrator termasuk dalam Computer Algebraic System (CAS). Software ini pertama kali diperkenalkan oleh Neven Jarkovis dari Softmath, San Antonio, Texas pada tahun 1990-an.

Software Algebrator adalah solusi math-tutoring lengkap, sesuai untuk memecahkan masalah matematika. Software Algebrator adalah sebuah aplikasi yang sangat baik untuk menyelesaikan semua masalah aljabar. Alat yang komprehensif ini akan memberikan siswa tidak hanya jawaban, tetapi juga semua langkah yang diperlukan untuk sampai ke solusi serta penjelasan lengkap dari masing-masing. (Kalantarnia et. al, 2012) menyatakan bahwa 
Software Algebrator dapat digunakan sebagai guru elektronik untuk siswa pada tingkat yang berbeda.

Sofware Algebrator mencakup masalah dari pra-aljabar sampai pada aljabar untuk perguran tinggi, trigonometri dan statistik. Dengan menggunakan software ini, kita tidak perlu tergantung pada buku matematika tertentu, karena software ini mampu memecahkan setiap soal matematika yang datang kepada siswa. Menurut Amiripour (2012) hal pertama yang menarik perhatian siswa ketika menggunakan Software Algebrator adalah tampilan yang sederhana dan jelas. Disisi lain, Kalantarnia, et.al (2012) menyatakan bahwa komputer dan Software dapat memberikan umpan balik real time kepada pengguna dan memimpin proses dalam kerangka kerja tertentu.

Pembelajaran yang dilakukan dengan berbantuan Software Algebrator disinyalir akan membuat pembelajaran matematika lebih bermakna, sehingga mampu mengantarkan siswa kepada pemahaman yang lebih komprehensif. Dahar (2011) informasi yang dipelajari secara bermakna dapat lebih lama diingat, memudahkan proses belajar berikutnya untuk materi pelajaran yang mirip, dan memudahkan belajar hal-hal yang mirip walaupun telah terjadi lupa. Hasil dari penelitian ini diharapkan dapat dijadikan sebagai bahan tambahan informasi dalam inovasi pembelajaran sehingga dapat menciptakan pembelajaran matematika yang mampu merangsang kemampuan berpikir siswa.

Hal tersebut sesuai dengan pendapat Ormrod (2009) yang menyatakan bahwa beberapa program komputer telah mampu meningkatkan berpikir tingkat tinggi (misalnya pemecahan masalah) dalam konteks tugas-tugas otentik atau yang menyerupai permainan. Berdasarkan latar belakang di atas, masalah penelitian difokuskan padaPembelajaran Matematika berbantuan Software Algebrator untuk meningkatkan kemampuan pemahaman matematis Siswa. Sementara itu, tujuan yang ingin dicapai dalam penelitian ini adalah mengkaji perbandingan kemampuan pemahaman matematis siswa yang menerapkan pembelajaran berbantuan Software Algebrator dan siswa yang menggunakan pembelajaran biasa dan menelaah perbedaan peningkatan kemampuan pemahaman matematis siswa yang menerapkan pembelajaran berbantuan Software Algebrator dan siswa yang menggunakan pembelajaran biasa.

\section{METODE}

Metode penelitian yang dipilih adalah penelitian kuasi eksperimen, karena subjek tidak dikelompokkan secara acak tetapi peneliti menerima keadaan subjek seadanya. Desain yang digunakan dalam penelitian ini adalah desain kelompok kontrol non-ekuivalen (non 
equivalent control group design). Pada desain eksperimen ini terdapat dua kelompok sampel, adanya pretest, perlakuan yang berbeda dan adanya posttest. Sampel pada kelompok pertama merupakan kelas eksperimen yang menggunakan pembelajaran berbantuan Software Algebrator.

Sementara itu kelompok kedua sebagai kelas kontrol yang mendapatkan pembelajaran menggunakan pembelajaran biasa. Adanya kelas kontrol ini adalah sebagai pembanding, sejauh manakah terjadi perubahan akibat perlakuan terhadap kelas eksperimen. Adapun diagram desain penelitian ini adalah sebagai berikut (Ruseffendi, 2005) :

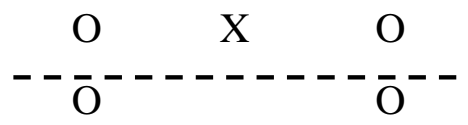

Keterangan:

$\mathrm{O}$ : Pretest dan Posttest berupa tes kemampuan pemahaman matematika.

X : Perlakuan menggunakan pembelajaran berbantuan Software Algebrator.

---- : Subjek tidak dipilih secara acak.

Populasi pada penelitian ini adalah seluruh siswa kelas VIII SMP Negeri 2 Kuningan yang berjumlah 384 orang siswa. Teknik pengambilan sampel dilakukan dengan menggunakan teknik purposive sampling. Alasan pemilihan sampel dengan purposive sampling karena kedua kelompok tidak dilakukan keacakan sesungguhnya, hanya berdasarkan kelas yang ada.Sampel yang dipilih dari adalah siswa kelas VIII-A yang dijadikan sebagai kelas eksperimen dan kelas VIII-C yang dijadikan sebagai kelas kontrol dengan jumlah siswa pada kedua kelas sebesar 84 orang siswa.Instrumen yang akan digunakan dalam penelitian berupa tes kemampuan pemahaman matematika. Pedoman penskoran tes disajikan pada tabel 1 berikut ini.

Tabel 1. Pedoman Pemberian Skor Pemahaman Matematis Menggunakan Holistic Scoring

\begin{tabular}{cl}
\hline Skor & \multicolumn{1}{c}{ Rubrics } \\
\hline 4 & $\begin{array}{l}\text { Kriteria } \\
\text { Menunjukkan kemampuan pemahaman: } \\
\text { b. Penggunaan konsep dan prinsip terhadap soal matematika secara lengkap. } \\
\text { dengan benar. }\end{array}$ \\
\hline 3 & $\begin{array}{l}\text { Menunjukkan kemampuan pemahaman: } \\
\text { a. Penggunaan konsep dan prinsip terhadap soal matematika hampir lengkap. } \\
\text { b. Penggunaan algoritma secara lengkap dan benar, namun mengandung sedikit } \\
\text { kesalahan dalam perhitungan. }\end{array}$ \\
\hline 2 & $\begin{array}{l}\text { Menunjukkan kemampuan pemahaman: } \\
\text { a. Penggunaan konsep dan prinsip terhadap soal matematika kurang lengkap. } \\
\text { b. Penggunaan algoritma, namun mengandung perhitungan yang salah. }\end{array}$ \\
\hline
\end{tabular}




\begin{tabular}{cl}
\hline Skor & \multicolumn{1}{c}{ Kriteria } \\
\hline 1 & $\begin{array}{l}\text { Menunjukkan kemampuan pemahaman: } \\
\text { a. Penggunaan konsep dan prinsip terhadap soal matematika sangat terbatas. } \\
\text { b. Jawaban sebagian besar mengandung perhitungan yang salah. }\end{array}$ \\
\hline 0 & $\begin{array}{l}\text { Menunjukkan kemampuan pemahaman: } \\
\text { Tidak ada jawaban, kalaupun ada tidak menunjukkan pemahaman konsep dan } \\
\text { prinsip terhadap soal matematika. }\end{array}$
\end{tabular}

Diadaptasi dan disesuaikan dari Cai, Lane, dan Jakabsin (1996)

Selanjutnya pada tahapan pengolahan data hasil penelitian, dilakukan prosedur sebagai berikut:

1. Memberikan skor pada jawaban siswa sesuai dengan alternatif jawaban dan sistem penskoran yang digunakan.

2. Membuat tabel skor pretest dan posttest siswa kelas eksperimen dan kelas kontrol.

3. Menghitung rerata skor tes tiap kelas.

4. Menghitung standar deviasi untuk mengetahui penyebaran kelompok dan menunjukkan tingkat variansi kelompok data.

5. Melakukan uji normalitas untuk mengetahui kenormalan data pretest, posttest, dan $\mathrm{N}$-gain secara keseluruhan dengan menggunakan uji Saphiro-Wilk.

6. Bila data tidak berdistribusi normal, maka dapat langsung dilakukan uji nonparametrik Mann-Whitney.

7. Jika data sudah memenuhi asumsi normal, maka selanjutnya dapat dilakukan uji homogenitas varians menggunakan uji Lavene. Bila variansi kedua kelas tidak homogen, maka dapat langsung dilakukan uji $t^{\prime}$.

8. Setelah asumsi normal dan homogen dipenuhi, maka selanjutnya dapat melakukan uji perbedaan dua rataan (uji-t) dengan menggunakan Compare Mean Independent Samples Test.

\section{HASIL DAN PEMBAHASAN}

\section{Hasil Penelitian}

Penelitian dilakukan untuk membandingkan kemampuan pemahaman matematis siswa yang merupakan efek dari pembelajaran yang dilakukan dengan Software Algebrator dan tanpa Software Algebrator. Pelaksanaan pembelajaran dengan menggunakan Software Algebrator diharapkan mampu membangun kemandirian belajar siswa, hal tersebut dimungkinkan karena melalui penggunaan Software Algebrator siswa akan dapat mengetahui langkah-langkah pengerjaan soal secara sistematis. Sebagaimana Kalantarnia, et.al (2012) bahwa Software Algebrator Ini adalah satu-satunya sistem khusus Aljabar yang terutama 
berfokus pada pendidikan matematika, pengguna bisa mengamati prosesnya melalui proses stepwise.

Setelah dilakukan pengolahan data skor pretes dan postes pada aspek kemampuan pemahaman matematik pada kelompok eksperimen dan kontrol, diperoleh statistik deskriptif sebagaimana ditunjukkan pada tabel 2 berikut:

Tabel 2. Statistik Deskriptif Skor Kemampuan Pemahaman Matematik

\begin{tabular}{llllll}
\hline \multirow{2}{*}{ Tes } & \multicolumn{5}{c}{ Kelompok Eksperimen } \\
\cline { 2 - 6 } & $\mathbf{N}$ & $\mathbf{X}_{\min }$ & $\mathbf{X}_{\text {maks }}$ & $\overline{\boldsymbol{x}}$ & $\mathbf{S d}$ \\
\hline Pretes & 42 & 1 & 10 & 6,17 & 2,67 \\
\hline Postes & 42 & 12 & 23 & 17,38 & 2,86 \\
\hline \multirow{2}{*}{ Tes } & \multicolumn{5}{c}{ Kelompok Kontrol } \\
\cline { 2 - 6 } & $\mathbf{N}$ & $\mathbf{X}_{\min }$ & $\mathbf{X}_{\text {maks }}$ & $\overline{\boldsymbol{x}}$ & $\mathbf{S d}$ \\
\hline Pretes & 41 & 1 & 10 & 6,15 & 2,64 \\
\hline Postes & 41 & 8 & 19 & 13,07 & 3,05 \\
\hline
\end{tabular}

Analisis tahap awal yang dilakukan dalam penelitian ini adalah melakukan analisis skor pretes. Analisis skor pretes dilakukan untuk melihat kemampuan awal siswa atau mengetahui apakah perbedaan skor rata-rata pretes siswa kelompok eksperimen dan kelompok kontrol yang dilakukan menggunakan Uji-t dengan Independent Samples Test karena persyaratan normalitas dan homogenitas telah terpenuhi, maka untuk mengetahui kesamaan rataan pretes kemampuan pemahaman matematik siswa pada kelompok ekperimen dan kelompok kontrol dihitung denganuji kesamaan rataan skor pretes menggunakan Uji-t dengan Independent Samples Test. Hasil analisis menyatakan bahwa rataan kemampuan awal pemahaman matematik siswa pada kelompok eksperimen sama dengan rataan kemampuan awal siswa pada kelompok kontrol dengan nilai signifikansi sebesar 0,972 yang artinya lebih besar dari $\alpha$ $=0,05$.

Selanjutnya, pada tabel 3 berikut ini disajikan rangkuman hipotesis penelitian, jenis uji statistik yang digunakan, dan hasil pengujian $\mathrm{H}_{0}$.

Table 3. Rangkuman Pengujian Hipotesis pada Taraf Signifikansi $\alpha=0,05$

\begin{tabular}{cccccc}
\hline No. & Hipotesis & $\begin{array}{c}\text { Perbedaan } \\
\text { Rerata }\end{array}$ & $\boldsymbol{t}$ & Sig. (2-tailed) & Pengujian H1 \\
\hline 1. & $\begin{array}{c}\text { Uji Perbandingan } \\
\text { Kemampuan }\end{array}$ & 4.308 & 6.634 & 0.399 & Diterima \\
\hline No. & Hipotesis & $\begin{array}{c}\text { Perbedaan } \\
\text { Rerata }\end{array}$ & F & Sig. (2-tailed) & Pengujian H1 \\
\hline 1. & $\begin{array}{c}\text { Uji Perbandingan } \\
\text { Peningkatan Kemampuan }\end{array}$ & 1.067 & 139.789 & 0.000 & Diterima \\
\hline
\end{tabular}




\section{Pembahasan}

Hasil penelitian menunjukkan bahwa siswa yang pembelajarannya berbantuan Software Algebrator memiliki kemampuan pemahaman matematik rata-rata yang lebih tinggi daripada siswa yang tidak menggunakan Software Algebrator. Hasil ini dimungkinkan karena melalui pembelajaran berbantuan Software Algebrator, guru sebagai fasilitator yang memberikan petunjuk-petunjuk dan saran dalam diskusi kelompok yang dilakukan oleh siswa ketika siswa merasa kesulitan dalam memahami dan menyelesaikan masalah sehingga siswa mendapatkan pemahaman yang lebih baik. Hindin (2009) menyatakan bahwa Algebrator adalah program Software yang memecahkan masalah aljabar dan memberikan penjelasan interaktif.Sementara itu, kegiatan-kegiatan tersebut tidak terjadi pada pembelajaran matematika yang tidak menggunakan Software Algebrator.

Secara umum, proses pembelajaran yang terjadi pada kelas eksperimen telah sesuai dengan rambu-rambu dan kriteria dan karakteristik pembelajaran berbantuan. Hal ini tercermin dari proses aktif siswa dalam diskusi, bertanya, menjawab permasalahan dengan lebih dari satu cara, menjelaskan dan menampilkan hasil pekerjaannya di depan kelas dan melakukan pengecakan jawaban dengan menggunakan Software Algebrator. Aktivitas siswa selama proses pembelajaran tampak pada berjalan lancar, meskipun pada awalnya siswa agak sedikit kaku dalam mengaplikasikan software tersebut. Hal tersebut dapat dimaklumi karena proses pembelajaran yang dilakukan denganagak berbeda dengan pembelajaran yang selama ini biasa mereka terima dari gurunya.

Pengalaman mengajar dan hasil belajar yang diperoleh siswa setelah mendapat pembelajaran matematika berbantuan Software Algebrator ini telah memberi motivasi kepada siswa untuk belajar dengan lebih mandiri. Hal tersebut sesuai dengan pendapat Kalantarnia et.al (2012) yang menyatakan bahwa Perangkat lunak ini dapat digunakan sebagai guru elektronik untuk siswa pada tingkat yang berbeda. Hasil temuan lain, selama proses pembelajaran matematika berbantuan Software Algebrator adalah siswa memiliki semangat mengikuti pembelajaran, pada setiap pembelajaran siswa memiliki ketertarikan terhadap masalah-masalah yang diberikan dalam pembelajaran untuk diselesaikan lalu masing-masing siswa mengecek kebenaran jawaban dengan menggunakan Software Algebrator.

Yulian (2016) menyatakan bahwa keuntungan menggunakan Software Algebrator yaitu: (a) Software Algebrator dapat menyelesaikan masalah matematis yang sulit sekalipun (semua level), (b) Software Algebrator dapat menyelesaikan masalah matematis dengan menggunakan metode tradisional ataupun modern, (c) Software Algebrator dapat menampilkan jawaban langkah-perlangkah dan menjadi tutor siswa dalam menyelesaikan 
masalah matematis, (d) Software Algebrator memvisualisasikan soal matematika ke dalam bentuk grafik. Selanjutnya, jika mencermati hasil penelitian yang telah dikemukakan menunjukkan bahwa pembelajaran matematika berbantuan Software Algebrator secara signifikan lebih baik dalam meningkatkan kemampuan pemahaman matematik siswa dibandingkan dengan pembelajaran yang tidak menggunakan Software Algebrator.

Antusiasme siswa terlihat dalam proses pembelajaran, terutama ketika mereka mampu menemukan sendiri konsep matematika dan cara penyelesaian soal yang mereka butuhkan dengan waktu yang relative singkat. Hal tersebut menggambarkan peran postif Software Algebrator dalam pembelajaran matematika. Yulian (2016) kemudian mendeskripsikan secara komprehensif bahwa melalui penggunaan Software Algebrator, siswa dapat (a) menemukan sendiri konsep dari materi yang dipelajari dan membangun pengetahuannya, (b) melakukan eksplorasi dan observasi dengan mudah, (c) menyelesaikan soal matematika dengan cepat dan akurat dalam pembelajaran, (d) bersikap lebih positif terhadap matematika.

Sementara itu Kusumah \& Yulian (2014) menyatakan bahwa dengan menerapkan Algebrator, siswa dapat (1) mengamati hasil pemecahan masalah mereka langkah demi langkah; (b) mengulangi aktivitas penyelesaian masalah yang sama setiap saat; (c) mengamati secara grafis masalah yang sulit ditemukan saat dilakukan secara manual; dan(d) meningkatkan motivasi siswa dalam melakukan latihan matematis. Beberapa alasan lain yang dapat dikemukakan sebagai perbandingan adalah bahwa pada pelaksanaan pembelajaran di kelas kontrol yang tidak menggunakan Software Algebrator, guru memberikan pembelajaran secara informatif. Guru memberikan penjelasan materi pelajaran secara terperinci, memberikan contoh cara menyelesaikan soal, serta memberikan latihan-latihan. Siswa memperhatikan penjelasan guru dengan seksama, kemudian mencatat apa yang dijelaskan guru dan mengerjakan latihan.

Sebelum siswa mengerjakan latihan, biasanya guru memberikan waktu kepada siswa untuk bertanya tentang hal-hal yang belum dipahaminya dan guru kembali memberikan penjelasan. Pada saat siswa mengerjakan soal-soal latihan yang diberikan, guru berkeliling memperhatikan cara siswa mengerjakan latihan dan membantu mengarahkan siswa yang mengalami kesulitan. Setelah waktu untuk mengerjakan soal habis, semua siswa mengumpulkan hasil pekerjaannya ke meja guru untuk dinilai. Untuk pembahasannya, beberapa siswa diminta mengerjakan soal tadi di papan tulis. Aktivitas siswa selama pembelajaran ini cenderung pasif dan tidak melatih kemandirian siswa dalam belajar dibandingkan dengan pembelajaran matematika berbantuan Software Algebrator. 


\section{SIMPULAN}

Berdasarkan hasil penelitian, diperoleh beberapa kesimpulan penelitian, yaitu kemampuan pemahaman matematik pada siswa yang pembelajarannya menggunakan pembelajaran matematika berbantuan Software Algebrator lebih baik daripada siswa yang tidak menggunakan Software Algebrator. Selanjutnya, peningkatan kemampuan pemahaman matematik siswa yang belajar dengan menggunakan pembelajaran matematika berbantuan Software Algebrator lebih baik daripada siswa yang tidak menggunakan Software Algebrator.

\section{DAFTAR PUSTAKA}

Amiripour, P. (2012). Mathematics Education through Algebrator Software." In International Journal of Emerging Trends in Enginering and Development, 2:1-7.

Cai, J., Lane, S., dan Jakabcsin, M.S. (1996). The role of open-ended task and holistic scoring rubrics: assessing students' mathematical reasoning and communication, dalam Communication in mathematicss K-12 and beyond, 1996 year book. National Council of Teachers of Mathematics.

Dahar, R. W. (2011). Teori-teori Belajar dan Pembelajaran. Jakarta: Erlangga.

Hendriana, H \& Soemarmo, U. (2014). Penilaian Pembelajaran Matematika. Bandung: Refika Aditama.

Hindin, H. J. (2009). Algebrator. Mathematics and Computer Education, 43(3), 286.

Kalantarnia, Z., Rostamy-Malkhalifeh, M., Shahvarani, A. A., \& Behzadi, M. H. (2012). The study of application of algebrator software for mathematical problems solving. Mathematics Education Trends and Research, 2012 (unknown), 1-7.

Khouyibaba. (2010). Teaching mathematics with technology. Procedia-Social and Behavioral Sciences, 9, (2010) 638- 643. http://dx.doi.org/10.1016/j.bbr.2011.03.031

Kusumah, Y. S., \& Yulian, V. N. (2014). Enhancing Students' Mathematical Reasoning By Algebrator-Assisted Inquiry Method. In International Seminar on Innovation in Mathematics and Mathematics Education. Departement of Mathematics Education Faculty of Mathematics and Natural Science Yogyakarta State University.

Lestari, A. (2008). Meningkatkan Kemampuan Pemahaman dan Penalaran Matematis Siswa SMA melalui Pembelajaran dengan Pendekatan Metakognitif. Tesis Magister pada SPs UPI Bandung: Tidak diterbitkan.

Ormrod, J. E. (2009). Psikologi Pendidikan. Jakarta: Erlangga.

Ruseffendi, E. T. (2005). Dasar-dasar Penelitian Pendidikan dan Bidang Non Eksakta Lainnya. Bandung: Tarsito.

Sumarmo, U. (2013). Berpikir dan Disposisi Matematik Serta Pembelajarannya. Bandung: Jurdikmat FPMIPA- UPI.

Tim MKPBM. (2001). Strategi Pembelajaran Matematika Kontemporer. JICA (Japan International Coorporation Agency/Badan Kerjasama Internasional Jepang) UPI. Bandung

Wena, M. (2013). Strategi Pembelajaran Inovatif Kontemporer: Suatu Tinjauan Konseptual Operasional. Jakarta: Bumi Aksara.

Yulian, V. N. (2016). Meningkatkan Kemampuan Pemecahan Masalah Matematis Siswa Melalui Metode Pembelajaran Metode Inkuiri Berbantuan Software Algebrator. Jurnal Penelitian dan Pembelajaran Matematika, 9(1). 